\title{
Needs Analysis and Implementation Training Management Model Development
}

\author{
Eka Daryanto ${ }^{1}$, Darwin ${ }^{2}$ \\ Educational Administration Department, Universitas Negeri Medan, Indonesia ${ }^{1,2}$ \\ ekadaryanto@unimed.ac.id
}

\begin{abstract}
This research aims to determine the design of need analysis and implementation training management model. This research uses descriptive qualitative approach method. The data is collected by interview, observation and documentation. The subjects of this research are lecturers, instructors, students and the stakeholders. The results shows that: 1) training courses at the department is using guided inquiry models, the training schedule has been set, the competence of the students is already fits to department vision and mission, 2) graduates are currently working in factories based on their Department during college term, and 3) Design teaching factory in the development of training management model enabling products paired with the industry, especially in performed by the students through the learning process.
\end{abstract}

Keywords: needs analysis, training management model.

\section{Introduction}

Improvement or development of human resources is a thing judged on the quality of education, so that education can play role it must be associated with the world of work, which means that graduates should have the ability and skills relevant to the demands of the working world[1]. Human resources play a big role hand in promoting the development of a nation. Development in the various sectors of human resources required to compete in national and international scale. The increase in employment without an increase in labor productivity can result in the impoverishment of the labor force due to stagnant wage [2]. Learning model is a series of presentation of teaching material that covers all aspects of learning in order to achieve learning objectives[3]. Vocational education and vocational education is a kind of education that specifically prepares students to enter the workforce after completing their studies by providing specific expertise. However, the research results showed that there are number of Unemployment Rate (TPT) is high for graduates of vocational and vocational education as stated in the figure below [4]:

In accordance with Law of Higher Education Article no. 16 Year 2012, the vocational education is education that prepares students to become professionals with skills / high workability [5]. Vocational education curriculum prepared jointly with the professional community and professional organizations are responsible for the quality of service in order to qualify profession professional competence. 


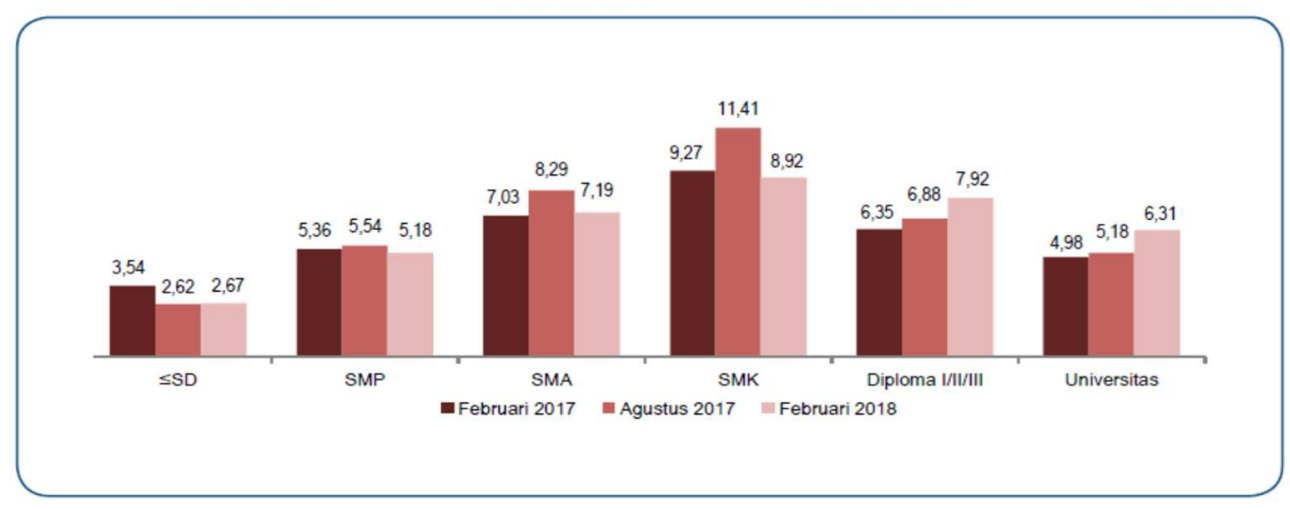

Fig 1. Unemployment Rate in $2017-2018$

There is amount up to $80 \%$ of educational quality problems caused by the management [6]. In order to improve the quality of vocational education, one of the solutions is to provide training. That process teach certain knowledge and skills and attitudes in order to obtain better skills and is able to carry out their responsibilities properly in accordance with the standards, the training should be done through careful planning or management model proper training [7].

Training planned to be managed in an organized, ranging from planning, organizing and controlling. The four functions of management affect the success of the organization in realizing the vision that has been formulated, even the failure of one of the management functions will result in failure to achieve the vision [8]. Some performance issues with members of organizations that require training are: (1) lack of ability of members, (2) lack of knowledge of members, (3) lack of motivation, (3) behavioral problems [9].

Training is an activity to improve the performance of current and future performance [10]. The benefits of training as are: to improve the independence, to increase the motivation, to generate a sense, to increase job satisfaction, and to improve corporate profits [11].

Regarding quality is an issue that has grown and received special attention in higher education, that is focus on quality in higher education triggered by a factor of the number of competitors, political oversight to higher education, as well as the growth and changes to the expected number of students [12]. There are dimensions of quality, namely: access to service, acceptance, efficiency, effectiveness, relevance to the needs, as well as equity [13].

Needs analysis is defined as a formal process to determine the distance or the gap between the output and the real impact the output and the desired impact, then placing a row this gap in the priority scale, and then choose what is more important to resolve the problem [14].

Training needs analysis is a systematic analysis that determines whether an employee/ employee need training or not. Training needs arise if there is a gap between the standards of performance with the work achieves. The process of training needs analysis is very important because it can provide information to organizations about the kind of training and development is needed by workers to improve the effectiveness and efficiency of the organization [15]. The process of training need analysis can be analyzed in several aspects, namely: organizational analysis, task analysis and individual analysis [16].

The terms of management or management training is describing, which covers the activities a) planning, b) implementation, c) evaluation [17]. Of the three components can be developed into a multiple step activity depend on the approach used. The focus of this research 
is the need analysis and implementation of the Teaching Factory in Training Management Model Development

\section{Research Method}

This study is a descriptive study with qualitative approach. Qualitative descriptive research type used in this research is intended to obtain in-depth information about the actual condition of management training, as well as factors that affect training. Subjects in the study is that lecturers, Chairman Prodi Diploma in mechanical engineering, Head of Production Unit, the business world Students and business / industry. Object of study in this research is the need analysis and implementation management model in the development of training management mechanical engineering state university school of engineering fields. The procedure of this research consists of four stages: Stage Pre Fields namely looking for a subject as a resource. Researchers conducted a field assessment (field study) against the background of research, looking for information and data from other studies about need analysis and implementation management model management training. It is intended to undertake the drafting of the study. The second phase: Field Work is to enter and understand the background of research in data collection. Third, the data analysis stage is conducted by performing a series of processes of qualitative data analysis and interpretation of the data that have been obtained previously. Then the process of triangulation of data is done as compared with the theory of literature. Fourth: Stage Evaluation and Reporting. This research instrument in the form of interviews, the instrument in the form of interview, observation, the instrument is a checklist and Documentation.

\section{Results And Discussion}

Training is one way to improve students' skills in mastering certain skills. The approach used in analyzing the needs of management training is to look at three components of a need analysis, i.e. organizational analysis, task analysis and individual analysis. Then the third aspect of the quality seen by Tovey quality theory, namely the quality of service access, acceptance, efficiency, effectiveness, relevance to the needs and equality. The training model used is guided inquiry. It is guided inquiry learning process with the guidance and direction of the instructor / trainer on an ongoing basis in accordance with the clock face in the classroom and in the practice room.

\section{a) Actual Condition of Competence Development}

Organizational Analysis, the training is done to improve the competence of students, especially in psychomotor. Facilities and infrastructure are used in the training Workshop / Workshop on Mechanical Engineering, with various laboratories in it among others: CNC Lab, Lab Machines, and so on. Lab Practical activities carried out in accordance with his courses. Basic machining tools are supplied complete, but still need a variety of machine tools that fit the needs of the industry. 
Task Analysis, each lecturer/instructor has job description, respectively, as set forth in Semester Lesson Plan. Each lecturer will get an assessment questionnaire distributed to student assessment, including an assessment based on student competency during the training process.

The training modules owned by the instructor is still very limited in number, there is even less likely. Lecturers that administer refer to instructional material, thus making the module or manual have not been realized.

Individual Analysis, The analysis focuses on the individual itself. This analysis deals with people who are in organizations that require training and development in a particular field. Individual work performance or results may be based on data and assessment of performance compared to the expected level of performance standards specified or organization.

\section{b. Needs Map}

The researchers have found the quality of several aspects in training management, which listed as follows:

Table 1. Percentage Of Training Quality

\begin{tabular}{llll}
\hline No & \multicolumn{1}{c}{ Quality } & \multicolumn{1}{c}{ Aspect } & Percentage (\%) \\
\hline 1 & Access to Service & Organizational & 90 \\
& & Task & 75 \\
& & Individual & 93.75 \\
2 & \multirow{4}{*}{ Acceptability } & Organizational & 58.5 \\
& & Task & 70 \\
& & Individual & 75 \\
3 & \multirow{2}{*}{ Efficiency } & Organizational & 79.16 \\
& & Task & 87.5 \\
& & Individual & 83.3 \\
4 & \multirow{2}{*}{ Effectiveness } & Organizational & 75 \\
& & Task & 91.67 \\
& & Individual & 62.5 \\
5 & \multirow{2}{*}{ Relevance to Needs } & Organizational & 62.5 \\
& & Task & 75 \\
& & Individual & 75 \\
6 & \multirow{2}{*}{ Equity } & Organizational & 68.75 \\
& & Task & 75 \\
& & Individual & 87.5 \\
\hline
\end{tabular}

Based on table analysis obtained by researchers, it is found that priority needs in the development of training management model are:

\section{a) Training model development}

Training management model currently in force in guided inquiry, the student gets assistance from the lecturer (instructor) during the training process. The problem appears when the students cannot find the appropriate solution to overcome the problems in the society. The students are lack of literature reviews so that they couldn't specify the needs of the society. Moreover, a training model which differs from the theory teaching model, since the training model has a lot of practices. Furthermore, the needs of integrated module are needed to guide the students in designing the machinery product.

One of obstacle in the training process is the lack of a Standard Operating Procedure (SOP) in ongoing training. Implementation of SOP training depends only on the existing courses, with 
the consideration that the training undertaken together with the subjects. The need for specific SOP will assist instructors during training indoors. SOP done by looking at the training management training models that already exists.

\section{b) Competence Test Centre}

The students' competence is currently marked by the work evaluation. The evaluation sheet does not have proper criterion, which compound the instructor to define students as competent enough or not.

This is because there is no place Competency Test should require Competency Test place as a tool to test their competency and give the certificate as reward, which can be used in applying for work after they graduate.

\section{c) Improved infrastructure}

Currently, focused in designing machine-based production with heavy equipment, such as iron, steel and aluminum also leads to the manufacture of basic materials of iron, steel and aluminum, while many industrialized world that does not use it anymore. The department needs to pay attention to the needs of infrastructure for light-based tools, such as polymers, etc. The aim is that the process of learning and training undertaken by students is suitable with the industrial world.

Design teaching factory formed in the development of training management model can be explained by the concept of management training. Training Management consists of planning, implementation and evaluation. The designs are grouped based learning, competence of graduates, the curriculum has been adopted, industry cooperation in the production process, the works carried out in the industry, and infrastructure. The design of the existing teaching factory is established in a design manual. Manual teaching factory design is user practical teaching factory used by students of three engineering diploma as a reference to do a job in accordance with the demand of the business / industrial world. Manual design formed in the management of this program: through the groove identify the problems that exist in society, analyze order, presented the results of orders, work orders, perform quality inspections, and receive presented the results obtained as well as get feedback (feedback) from the lecturer / instructor.

Aspects of the evaluation process and the evaluation show the measure of success of the implementation of the teaching factory. Evaluation is required to see the achievement obtained from the product, both qualitatively and quantitatively. The evaluation is conducted by the coordinator. It is to conduct assessment work on each part of the production execution. Starting from the content, input, process and product. The evaluation results per section are then reviewed again in the overall assessment and the results used as the basis for continuous improvement. Measure of the success could be seen by the achievement of targets, the time completion of products, and consumer satisfaction. Evaluation is done in a sustainable manner is merely a subjective assessment. No indicators and instruments as a reference to determine the target.

In the learning process carried out also allows third parties can order special order products can also be made or produced by students in the school facilities through prior analysis. This design is expected to be one of the trimmers bridge the distance between the competence of graduates with the competence needs of the industry, especially industrial partner. Manual design teaching factory in the development of training management model consists of ways of working that can be used by a student to do a job in the learning process. Quality control and follow-up teaching factory in the development of training management model used to improvement needs of the workforce. Readiness of students to enter the working world can be 
done by strengthening and improving the efficiency and academic competence, both financial incentives to encourage industry in the provision of internships and develop a curriculum aligned with the employment needs based on input from the business / industrial world. The success of teaching factory

\section{Conclusion}

1. The actual condition of the implementation of the increase in student competence namely: (1) The training is done with a model of guided inquiry such as mentoring by faculty as an instructor for one semester, (2) The training activities together with existing courses as a form of practice of the theory taught in the lecture, and (3) Workshop has had a fairly complete Laboratory, such as Smart Lab and CNC Lab. The machining tools are used to concentrate the iron, steel and aluminum.

2. Map design development needs training to improve competency management model student priority to: Competency Test Centre, Improved infrastructure and Management training is focused on SOP in accordance with the models of existing training.

3. Design teaching factory in the development of training management model enabling products paired with the industry, especially in performed by the students through the learning process. In planning the educational institutions and industry negotiations to determine which products do students with existing facilities, but these products have a sale value that can be accepted by consumers and the industry itself.

\section{References}

[1] Supriadi, "No Title," in Pendidikan Bahasa Indonesia 2, Jakarta: CV Pustaka, p. 54. (1996)

[2] I. L. Organization, Laporan Ketenagakerjaan Indonesia: Memanfaatkan Teknologi untuk Pertumbuhan dan Penciptaan Lapangan Kerja. Medan: Unimed, (2017).

[3] Suprijono and Agus, "No Title," in Cooperative Learning, Teori dan Aplikasi PAIKEM., Yogyakarta: Pustaka Pelajar, p. 46. (2013)

[4] B. P. Statistik, Keadaan Ketenagakerjaan Indonesia Agustus 2018. (2018).

[5] . . Law of Higher Education Article no. 16 Year 2012. (2012).

[6] H. Usman, Manajemen Teori: Praktek dan Riset Pendidikan. Jakarta: Bumi Aksara, (2008).

[7] M. Muslihin, "Evaluasi Program Pendidikan dan Pelatihan Kepemimpinan Tingkat IV Pemerintah Provinsi Nusa Tenggara Barat," JTP - J. Teknol. Pendidik, vol. 18, no. 1, p. 22, 2017, doi: 10.21009/jtp1801.3. (2017)

[8] W. Pangaribuan, Pengaruh Budaya Organisasi, Komitmen Organisasi, Komunikasi Interpersonal dan Efektivitas Sistem Pengendalian Manajemen Kinerja terhadap Kinerja Dosen. Dr. Thesis, (2017).

[9] D. Leigh, The Group Trainers Handbook: Designing And Delivering Training For Groups. London: Kogan Page, (2006).

[10] V. Rivai, Manajemen Sumber Daya Manusia untuk Perusahaan. Jakarta: Grafindo, (2010).

[11] Suparyadi, Manajemen Sumber Daya Manusia. Yogyakarta: Andi, (2015). 
[12] et al. C. Nair., Leadership and Management of Quality in Higher Education. United Kingdom: Chandos Publishing, (2010).

[13] P. Tovey, Quality Assurance in Continuing Professional Education, An Analysis. New York: Routledge, (1994).

[14] W. F. E. R. Kaufman., Need Assesments Concept and Aplication. New Jersey: Educational Technology Publications, (1979).

[15] D. Hanggraeni, Manajemen Sumber Daya Manusia. Jakarta: Lembaga Penerbit Fakultas Ekonomi Universitas Indonesia, (2012).

[16] J. M. W. Mondy., Human Resource Management. USA: USA: Pearson Education Limited, (2016).

[17] Elfrianto, Manajemen Pelatihan Sumber Daya Manusia Dalam Meningkatkan Mutu Lulusan, EduTech J. Ilmu Pendidik. dan Ilmu Sos., vol. 2, no. 2, pp. 46-58, (2016). 